УДК 37.015.31:33:316.614

DOI:

Олександр Шпак, доктор педагогічних наук, професор Національного педагогічного університету імені М.П. Драгоманова, м. Київ

Світлана Булавенко, кандидат педагогічних наук, докторант Інституту проблем виховання НАПН України

Наталія Примаченко, кандидат педагогічних наук, член Національної спілки журналістів Украӥни Дрогобииький державний педагогічний університет імені Івана Франка

\title{
ЕКОНОМІЧНА ОСВІТА ЯК ЧИННИК СОЦІАЛІЗАЦІЇ ШКОЛЯРІВ
}

В умовах трансформаційних змін в Украӥні спостерігаються динамічні та глибокі зміни у сочіальних характеристиках населення в цілому, зокрема молодшого покоління. Важливе місце в економічній сочіалізації займає економічні потреби, характер і реалізація яких сприяють включенню особистості в соціальну діяльність, формуючи його економічну свідомість.

У статті йдеться про актуальність економічної соціалізачії учнів, розглядається поняття та складові економічної сочіалізачії школярів, аналізуються шляхи економічної сочіалізації, приділясться значна увага основним вимогам знань і вмінь учнів у галузі економіки.

Ключові слова: економічна сочіалізація; економічна освіта; иіннісні орієнтації; иляхи формування економічної соиіалізації.

Jim. 8.

Oleksandr Shpak, Doctor of Sciences (Pedagogy), Professor National Mukhaylo Drahomanov Pedagogical University, Kyiv Svitlana Bulavenko, Ph.D.(Pedagogy), Doctoral Student of the Institute of Education Problems of the National Academy of Sciences of Ukraine Nataliya Prymachenko, Ph.D.(Pedagogy), Member of the National Union of Journalists of Ukraine Drohobych Ivan Franko State Pedagogical University

\section{ECONOMIC EDUCATION AS FACTOR OF SOCIALISATION OF SCHOOLS}

Economic socialization is considered as a process of formation of economic thinking, including the formation of internal structures of the human psyche through the assimilation of a new reality, which includes knowledge of economic reality, the absorption of economic knowledge and the acquisition of skills of economic behavior. The purpose of economic socialization is to develop the adequate representations of economic categories, development of skills of economic behavior. In many ways, economic socialization coincides with the goals and objectives of economic education, since it is carried out using the same means and methods of influencing on the economic consciousness. The main institutes of the formation of economic socialization of the individual are institutions of general secondary education. Thus, it is clear that the main form of economic socialization of students is the formation of economic knowledge and skills, as well as the economic upbringing of the young generation.

Economic socialization of students must begin with elementary school and carry on for all years of studying in an educational institution, as it is the mastery of the basics of economic knowledge leads to awareness of the role of education as a guarantor of competitiveness in the labor market. We can distinguish the following components in the structure of economic socialization: cognitive components and factors (perceptions and representations, irrational and rational in economic thinking, decision-making process and implementation of economic choices); affective components and factors (the role of emotions and feelings in making economic decisions, the impact of advertising); components of the actual economic behavior.

Consequently, the economic socialization of students is a process of forming the economic ideas that provide an individual with the ability to achieve their goals through interaction with the economic system. The most structured parts of the factors of economic socialization are social institutions, among which the most important is education. An important place in economic socialization is occupied by economic needs, the nature and implementation of which contribute to the inclusion of personality into social activities, forming its economic consciousness. In the conditions of the transformational changes in Ukraine there are dynamic and profound changes in social characteristics of the population as a whole, as well as of the young generation in particular. In this case, social representations of the personality, the state and content of which will determine in the near future sustainable development of Ukrainian society.

Keywords: economic socialization; an economic education; value orientations; the ways of formation of economic socialization.

П остановка проблеми. Наявність економічного компонента практично у всіх сферах діяльності сучасної

людини зумовлює затребуваність економічної освіти молоді як передумови майбутньої успішної самореалізації. Тобто виникає об'єктивна потреба 
в економічній соціалізації особистості, як процесу засвоєння індивідом економічних інтересів і нагальних потреб; оволодіння різними соціально - економічними ролями; розвитком активності і вибором соціально схвалюваної економічної поведінки.

Школа вже протягом тривалого історичного часу $\epsilon$ провідним чинником соціалізації особистості. Відповідно до викликів часу і проблем соціального становлення особистості пошук нових моделей розвитку освітнього простору, спрямованого на забезпечення соціально-педагогічних умов успішної соціалізації дитини, зокрема, економічної, впроваджується сьогодні в закладах загальної середньої освіти. Вже тривалий час економіка входить до інваріантної складової старших класів навчальної програми школи [7].

Проте, одним із серйозних недоліків викладання економіки в школі - недостатній зв'язок предмета 3 життям. Найчастіше уроки зводяться до лекцій з теорії, тоді як шкільний курс 3 цього предмету повинен, перш за все, навчити дітей орієнтуватися в умовах ринкової економіки - знати свої права і вміти ними користуватися. Тому, на наш погляд, в основу економічної освіти у школі повинен бути покладений діяльнісно-орієнтований підхід, суть якого - у формуванні в учня не тільки знань, а й умінь застосовувати їх на практиці. Адже саме такий підхід найповніше реалізує економічну соціалізацію учнів.

Метою статті $\epsilon$ ознайомлення 3 поняттям економічної соціалізації учнів та визначити шляхи реалізації цього напрямку формування особистості в $33 \mathrm{CO}$.

Аналіз актуальних досліджень. Досліджуючи принципи і основні напрямки економічної освіти в загальноосвітній школі, В.В. Анісімов, О.Г. Грохольська акцентували увагу на якісній стороні підготовки школярів до життя в суспільстві шляхом внесення відповідних коректив в систему підготовки до продуктивної праці і економічного виховання [8]. В.К. Розов, І.Ф. Прокопенко, Л. І. Паномарев, О.В. Плахотник розглянули питання теорії і методики економічного виховання школярів, приділяючи особливу увагу формуванню в учнів таких якостей, як ощадливість, економність.

Поряд 3 поняттям економічної освіти, виділяють поняття економічного виховання. На думку С.Г. Юсупової, мета i завдання економічного виховання ширше і багатогранніше. Н.І. Бєлкіна зазначає, що економічне виховання $€$ важливим чинником економічної освіти людини
[3]. Такої позиції дотримуються багато дослідників Ю.К. Васильєв, Г.Д. Глібова, Ф.П. Євсеєнко, О.Н. Єсіна, Т.М. Кондратенко, В.С. Ковальова, М.А. Лобанова, Е.Н. Неустроєва, Н.П. Сабельфельд роботи, яких присвячені проблемам економічного виховання та економічної освіти школярів. Як зазначає Е.Н.Землянська, в процесі економічного виховання економічні знання перетворюються в переконання і реалізуються у вчинках і поведінці. Формування у школярів економічних якостей особистості розглядалися в роботах М.Л.Алфьорової, Е.В. Савіної, Т.С. Сергєєвої, В.А. Семеніхіна.

У процесі вивчення публікацій зазначених авторів відзначаємо, що якщо раніше першорядне значення надавалося формуванню таких якостей, як ощадливість, працьовитість, то тепер ряд економічних якостей особистості, які формуються у шкільному віці розширився і в нього увійшли наступні якості: організованість, відповідальність, послідовність, цілеспрямованість, планомірність, старанність, самокритичність, активність. При цьому відзначається наявність здатності, яка забезпечує накопичення знань, вироблення умінь і освіту спонукальних мотивів, прагнення досягати в повсякденній практичній діяльності найбільших результатів при найменших витратах [2].

Виклад основного матеріалу. Соціалізація людини відбувається через певні інститути групи, які виступають передавачами норм, цінностей і досвіду. В. А. Іванченко говорить про те, що такими інститугами є: сім'я людини, освітнє і трудове середовище, засоби масової інформації [3]. Крім інститутів соціалізації виділяють ще агентів соціалізації, які є провідниками, активними передавачами досвіду. До них відносяться батьки, друзі, педагоги, члени референтної групи, певні варіанти 3МI (наприклад, для когось це групи в соціальній мережі, а для іншого - аналітичні журнали), книги тощо. Проте сьогодні реалії життя диктують посилення саме економічної складової соціалізації особистості, тобто нагальною стає саме економічна соціалізація.

Економічна соціалізація розглядається як процес становлення економічного мислення, в тому числі формування внутрішніх структур людської психіки завдяки засвоєнню нової реальності, що включає пізнання економічної дійсності, засвоєння економічних знань і набуття навичок економічної поведінки [6].

Метою економічної соціалізації є вироблення адекватних уявлень про економічні категорії, розвиток навичок економічної поведінки. Багато в чому економічна соціалізація збігається з цілями і завданнями економічного виховання, оскільки вона здійснюється 3 використанням тих же 


\section{ЕКОНОМІЧНА ОСВІТАЯК ЧИННИК СОЦАЛЗАЦЇ ШКОЛЯРІВ}

засобів і методів впливу на економічну свідомість [4].

Основними інститутами формування економічної соціалізації особистості є заклади загальної середньої освіти.

Існує багато точок зору на визначення підходів до викладання школярам економічних знань. Проте, на практиці реалізуються чотири основні підходи: бізнес-орієнтований, теоретизований, культурно-функціональний, академічний.

Професійно-орієнтований підхід полягає в тому, щоб виробити навички поведінки в господарському житті, систематизувати корисні економічні знання. Цей підхід акцентує увагу на викладанні прикладних дисциплін. Недолік підходу в тому, що такі поради часто не можливо реалізувати в школі, тому в учнів складається занадто абстрактне уявлення про науку, і немає стимулу до вивчення предмета, так як незрозуміло, як можна застосувати отримані знання.

Теоретизований підхід передбачає, що шкільна економічна освіта буде являти собою спрощену академічну, університетську. У разі застосування такого підходу виходить, що школярам викладається кілька економічних курсів, які часто не пов'язані. Викладання не пов' язаних між собою економічних дисциплін дає учням занадто багато інформації, яку важко систематизувати і застосовувати в майбутньому [7].

Культурно-функціональний підхід прагне до формування загальної культури, виробленню адекватних уявлень про світ, суті економічних явищ і процесів. Цей підхід полягає в прищепленні школярам функціональної економічної грамотності, формування здатності до розвитку, в тому числі до саморозвитку та самоосвіти, формування системи цінностей і розвиток індивідуальності, вироблення навичок господарської діяльності в різних економічних умовах. Культурнофункціональний підхід найбільш підходить для викладання економіки в середній школі, так як дозволить сформувати саме загальну економічну культуру і грамотність, необхідну кожній людині в житті.

Ще один підхід - академічний, найбільш популярний на сьогоднішній день. Він міститься в офіційній навчально-методичній літературі 3 економіки і являє собою спрощене, але цілісне уявлення про основи економіки, він передбачає поступове ускладнення від класу до класу, щоб створити в учнів базу для вивчення економіки в вузах. Переваги такого підходу в тому, що школярам дається системне знання про предмет, при цьому підхід передбачає перехід від основ до більш складного матеріалу. Недоліком цього підходу можна вважати занадто великий обсяг матеріалу, що вивчається, а так само непрактичність і неможливість застосування в реальному житті знань, які даються учневі. Окрім того тільки деякі школи можуть дозволити собі викладання економіки починаючи 3 молодшої школи, з причини не можливості фінансування [5].

Отже, зрозуміло, що основним шляхом економічної соціалізації школярів $\epsilon$ формування економічних знань та вмінь, а також економічне виховання підростаючого покоління. Варто зазначити, що формувати економічні знання i вміння необхідно з раннього віку, але цілі економічної підготовки на різних етапах розвитку учнів будуть різними.

У початковій школі (1 - 4-х класів) мета економічної підготовки - сформувати у дітей розуміння процесів, які відбуваються в сучасному суспільстві, дати навички колективних дій i стимулювати різнобічну активність дітей. У початковій школі економічна підготовка повинна здійснюватися за рахунок міжпредметних зв'язків на уроках $з$ основних шкільних предметів, таких як “Економіка і основи здоров’я”, “Економіка i трудове навчання”, “Економіка і література”, "Економіка і математика" тощо.

Метою економічної підготовки учнів основної школи (5 - 9-х класів) є формування розуміння економічних, соціальних і політичних відносин в суспільстві, усвідомлення цінності освіти та їі необхідності для кваліфікованого виконання будьякої роботи. При цьому модель економічної освіти учнів цих класів загальноосвітньої школи заснована перш за все на принципі безперервності освіти. Економічна підготовка учнів основної школи необхідна для того, щоб учні могли зробити усвідомлений і раціональний вибір майбутньої професії [6].

Мета економічної підготовки учнів старшої школи (10 - 11-х класів) - зацікавити їх у безпосередній участі в житті суспільства і демократичних процесах. У центрі вивчення курсу - взаємини між виробництвом, навколишнім середовищем, використанням обмежених природних ресурсів.

При виборі моделі економічної освіти учнів 9-х та 11-х класів слід пам'ятати, що ці класи випускні. Частина випускників як 9-х, так і 11-х класів почнуть самостійне трудове життя, частина продовжать свою освіту в спеціальних навчальних закладах, тому важливо не тільки познайомити учнів $з$ економічними засадами суспільства, а й сформувати у них основи економічної культури.

Отже, економічну соціалізацію учнів необхідно 
починати з початкової школи і здійснювати протягом усіх років навчання в освітній установі, так як саме оволодіння основами економічних знань призводить до усвідомлення ролі освіти як гаранта конкурентоспроможності на ринку праці.

Таким чином під економічною соціалізацією учнів ми розуміємо формування в підростаючого покоління вміння включатися в процес економічних відносин суспільства, засвоєння досвіду цього суспільства і активне його відтворення.

Інакше кажучи, під економічною соціалізацією мається на увазі процес, в рамках якого діти засвоюють норми діяльності в економіці, а саме: розпоряджаються грошовими коштами, роблять покупки, планують бюджет тощо [2].

Спираючись на дослідження О.С. Дейнеки, Ж.А. Жиліної, А.Л. Журавльова та Н.А. Журавльової, А.С. Євдокимова, А.П. Вяткіна, ми можемо виділити наступні компоненти в структурі економічної соціалізації:

- когнітивні компоненти і фактори (сприйняття і уявлення, ірраціональне і раціональне в економічному мисленні, процес прийняття рішень і здійснення економічного вибору);

- афективні компоненти і фактори (роль емоцій і почуттів у прийнятті економічних рішень, вплив реклами);

- компоненти власне економічної поведінки [3].

Розглядати економічну соціалізацію в 33СО слід в єдності наступних аспектів: цілі та завдання, зміст і організація, функції і педагогічні умови економічного навчання і виховання учнів.

Формування економічних знань і вихованості має відбуватися за допомогою ціннісного освоєння економічної діяльності. Дана мета розкривається в задачах економічного виховання:

- розвиток економічного мислення;

- формування морально-економічної спрямованості особистості;

- набугтя практичних навичок і форм поведінки [4].

У змісті економічного виховання та навчання ми виділяємо наступні компоненти: емоційнопізнавальний (усвідомлення економічних понять і їх взаємозв' язок), ціннісно-моральний (має на увазі ціннісне ставлення до навколишнього світу, повагу до праці людей, розвиток працьовитості) i перетворюючий (вміння добувати необхідні знання та застосовувати їх в діяльності).

Саме ці компоненти найбільшою мірою сприяють вирішенню завдань економічної освіти, а також враховують вікові особливості дітей.

Економічна освіта $є$ фактором економічної соціалізації школярів, завдяки якій в особистості формуються ціннісні орієнтації.
Варто відмітити, що поряд 3 економічною освітою в школі, діти в сім'ях отримують певні уявлення про різні економічні явища і події. Батьки привчають їх до праці, наприклад господарськопобутової, або просять допомогти у вихованні молодших дітей, видають їм кишенькові гроші тощо. В залежності від того, на які цілі витрачаються ці гроші і які умови їх отримання, вже у віці 3 - 5 років закладаються психологічні передумови для засвоєння того чи іншого типу економічної поведінки.

Динаміку ціннісних орієнтацій особистості, поряд зі шкільною економічною освітою зумовлюють як об'єктивні, так і суб'єктивні характеристики дітей, батьків і родини в цілому (незалежні змінні). Серед них слід виділити:

1) структуру сім'ї: склад сім'ї (повна / неповна; кількість дітей), розмір сім'ї (визначається за кількістю членів сім’ї);

2) економічний статус сім'і (по сукупному доході сім’і);

3) соціально-демографічні характеристики батьків: вік, освіта (в тому числі наявність / відсутність професійної економічної);

4) соціально-психологічні характеристики особистості батька, який брав участь в дослідженні: ціннісні орієнтації, установки на економічне виховання дітей (видача кишенькових грошей, статті дитячих витрат, рання трудова зайнятість дітей тощо);

5) показники економічного статусу дитини: наявність / відсутність кишенькових грошей; досвід поводження з грошима (визначається тривалістю часу видачі батьками кишенькових грошей);

6) ступінь задоволеності матеріальним доходом сім'ї;

7) індивідуальні характеристики дитини: стать, показники успішності в навчанні як непрямі оцінки рівня розумового розвитку;

8) показники соціальної активності школяра [7].

Більшість батьків, чиї діти навчалися основам економічних знань в школі, вважають, що діти можуть 314 років заробляти, і це сприяє формуванню у них особистісних якостей, необхідних для життя. Оскільки зміни в свідомості дітей нерідко виникають тоді, коли відбувається накопичення інформації, що досягає певної критичної маси, то можна припустити, що дана батьківська установка засвоєна дітьми.

Економіко-психологічний статус надає впевненість людині в завтрашньому дні, сприятливо позначається на активності, пов'язаній iз значущістю таких вольових якостей, як 
рішучість, самостійність, наполегливість тощо. То ж, впевненість батьків в своєму матеріальному благополуччі також може впливати на значимість вольових цінностей в свідомості дітей. Система економічних знань і виховний вплив школи посилюють їх вплив на вольові ціннісні орієнтації дітей [2].

На підвищення значущості в свідомості школярів матеріальних цінностей (мати можливість багато заробляти і витрачати гроші, збирати і колекціонувати, добре одягатися, дотримуватися моди тощо) поряд зі школою впливають освітній статус батьків і особистий досвід поводження дітей $з$ грошима. Ці фактори не тільки визначають особистісні якості школярів (ощадливість, економність тощо), а й формують у них уявлення про значущість матеріальних благ як результат праці інших людей. Якщо дитина отримує гроші просто так, а не за роботупо дому або оцінку, то мотив грошей не виходить на перший план і не підпорядковує собі особистість [8].

Дитина усвідомлює багатство як необхідну передумову гідного способу життя. Така особистість прагне досягти економічного успіху і незалежності для того, щоб матеріальні проблеми перестали бути значимими для неї, а економічне благополуччя забезпечило можливість задоволення інших, наприклад культурних, потреб. Підвищення значущості такої цінності, як висока соціальна активність, також пов'язане 3 особистим досвідом поводження дітей з грошима. Дійсно, вміння розпоряджатися кишеньковими грошима - планувати їх витрати, економити, витрачати, вкладати тощо - передбачає наявність у дитини певної активної позиції у взаєминах 3 навколишнім соціальним світом [8].

Висновок. Отже, економічна соціалізація учнів - це процес формування економічних уявлень, які забезпечують особистості здатність досягати своїх цілей за допомогою взаємодії 3 економічною системою. Найбільш структуровану частину чинників економічної соціалізації складають соціальні інститути, серед яких найважливішим є освіта. Важливе місце в економічній соціалізації займають економічні потреби, характер і реалізація яких сприяють включенню особистості в соціальну діяльність, формують іiі економічна свідомість. В умовах трансформаційних змін в Україні відбуваються динамічні та глибокі зміни соціальних характеристик як всього населення, так і підростаючого покоління зокрема. При цьому формуються соціальні уявлення особистості, стан і зміст яких визначать в недалекому майбутньому стійкий розвиток українського суспільства.

\section{ЛІТЕРАТУРА}

1. Белінська О. П., Тіхомандріцька О. О. Соціальна психологія особистості / О.П. Белінська, O.О. Тіхомандріцька. - М .: Academia, 2009. $304 \mathrm{c}$.

2. Вяткін А. П. Психологія економічної соціалізації особистості: суб'єктно-рольовий підхід: монографія / А.П. Вяткін. - Іркутськ: ІДУ, 2010. $-383 \mathrm{c}$.

3. Загребин В. В. Підходи до визначення категорії “економічна соціалізація" // Науковометодичний електронний журнал “Концепт”. 2014. - № 2 (лютий). - C. 6. - URL: http://ekoncept.ru/2014/14030.htm.

4. Іванченко В. А. Зовнішні та внутрішні детермінанти процесу соціалізації підлітків 3 неповних сімей: монографія / В.А. Іванченко. К: ДСГУ, 2015. - С. 180.

5. Лелека С.В. Активізація пізнавальної діяльності учнів на уроках економіки / С.В. Лелека // Економіка в школах України. - 2006. - №4(17) - C. $8-11$.

6. Овсюк Н. Формування економічної компетентності у процесі вивчення географії та основ економіки / Н. Овсюк // Географія та основи економіки в школі. - 2011.- № 1. - С. 37-41.

7. Овчарук О. Компетентність як ключ до оновлення змісту освіти / О. Овчарук // Стратегія реформування освіти в Україні. - К.: “К.І.С.”, 2003. - C. 13-41.

8. Топузов О. Компетентнісний підхід до навчання / О. Топузов, Л. Вішкініні //Географія та основи економіки в школі. - 2011. - № 5. - С. 34-37.

\section{REFERENCES}

1. Belinska, O.P. \& Tichomandritska, O.O. (2009). Sotsialna psichologiya osobystosti [Social psychology of personality]. Moscov: Academia, 304 p. [in Ukrainian].

2. Vyatkin, A. P. (2010). Psichologiya ekonomichniyi sotcializatsii osobystosti: subyektno-rolovy pidchid: мonjgrafiya [Psychology of economic socialization of the individual: the subjective-role approach: monograph]. Irkutsk: IDU, 383p. [in Ukrainian].

3. Zagrebyn, V.V. (2014). Pidchody do vyznachennya kategorii "ekonomichna sotcializatsiya" [The approaches to the definition of the category "an economic socialization"]. The scientific and methodical electronic "Consept", no. 2, p. 6. Available at: http://e-koncept.ru/2014/14030.htm. [in Ukrainian].

4. Ivanchenko, V.A. (2015). Zovnishni ta vnutrishni determinant protcesu sotsializatcii pidlitkiv $z$ nepovnych simey: мonjgrafiya [The external and internal determinants of the process of 


\section{АРТИСТИЗМ ЯК НЕОБХІДНАСКЛАДОВАМУЗИЧНО-ВИКОНАВСЫКОӤ КОМПЕТЕНЦЇ МАЙБУТНЬОГО ВЧИТЕЛЯ МУЗИЧНОГО МИСТЕЦТВА}

socialization of adolescents from the single-parent families: monograph]. Kyiv: DSGU, p.180. [in Ukrainian].

5. Leleka, S.V. (2006). Aktuvizatsiya piznavalnoi diyalnosti uchniv na urokach ekonomiky [An activation of cognitive activity of students at economics lessons]. Economics in schools of Ukraine, no.4(17), pp. 8 - 11. [in Ukrainian].

6. Ovsyuk, N. (2011). Formuvannya ekonomichnoi kompetentnosti u protsesi vuvchennya geografii ta osnov ekonomiky [The formation of economic competence in the process of studying Geography and Fundamentals of Economics]. Geography and Basics of Economics in School, no. 1, pp.37-41. [in Ukrainian].

7. Ovcharuk. O. (2003). Kompetentnist yak klyuch do onovlennya zmistu [Competence as a key to updating the content of education]. A strategy of reforming the education in Ukraine. Kyiv: "K.I.S", pp. 13-41. [in Ukrainian].

8. Topyzov, O. \& Vishкinini, L. (2011). Kompetentnisny pidchid do navchannea [Competency approach to learning]. Geography and Basics of Economics in School, no. 5, pp. 34-37. [in Ukrainian].

УДК [378.091.212:78.071.2]005.336.5

DOI:

Марина Білецька, кандидат педагогічних наук, доцент, завідувач кафедри інструментального виконавства та музичного мистеитва естради Мелітопольського державного педагогічного університету імені Богдана Хмельницького

Тетяна Підварко, старший викладач кафедри інструментального виконавства та музичного мистецтва естради

Мелітопольського державного педагогічного університету імені Богдана Хмельницького

\section{АРТИСТИЗМ ЯК НЕОБХІДНА СКЛАДОВА МУЗИЧНО-ВИКОНАВСЬКОӤ} КОМПЕТЕНЦЇ̈ МАЙБУТНЬОГО ВЧИТЕЛЯ МУЗИЧНОГО МИСТЕЦТВА

У статті розглянуто проблему підготовки майбутнього вчителя музичного мистецтва, розкрито поняття “артистизму” та його значення у структурі музично-виконавській компетениій майбутнього вчителя музичного мистецтвва.

Констатовано, щуо артистизм є необхідною складовою особистісно-когнітивного компоненту структури музично-виконавської компетенції майбутнього вчителя музичного мистецтва, адже яскраво виражений артистизм допоможе зміцнити в учнів інтерес до музики та до занять з музичного мистецтвва.

Ключові слова: артистизм; творча уява; виконавські уміння; виконавська майстерність, компетенція.

Jim. 10.

Maryna Biletska, Ph.D.(Pedagogy), Associate Professor, Head of the Instrumental Performance and Arts of Pop Music Department Melitopol Bohdan Khmelnytskiy State Pedagogical University

Tetyana Pidvarko, Senior Lecturer of the Instrumental Performance and Arts of Pop Music Department Melitopol Bohdan Khmelnytskiy State Pedagogical University

\section{ARTISTRY AS ANEEDED COMPONENT OF MUSICALLY-CARRYING OUT COMPETENSE OF FUTURE TEACHER OF MUSICAL ART}

The problem of preparation of future teacher of musical art is considered in the article, concept "artistry" and the value are exposed in a structure of the musically-carrying out competence of future teacher of musical art.

It is established, that artistry is a necessary component of personality and the component of structure of musically-carrying out competence of future teacher of musical art, and in fact the brightly expressed artistry will help to fix the students' interest to music and to employments after studying the musical art.

A musically-carrying out competence gives an opportunity to the teacher of musical art more fully to expose the individual professionally meaningful features: emotionality and expressiveness, reflexivity and creativity, and also volitional qualities. Artistry is containing many constituents. They are the stage of inspiration, and possibility to make alteration by improvisation in implementation in the process of live performance, and ability to underline the best lines of own creative personality. Artistry is the result of cooperation of carrying out the mastery of performer and creative contact with listeners. If the teacher of musical art will not be able to lay hands on attention of schoolchildren-listeners and at the same time to feed the emotional support, then there is the testifies of absence of artistry, without that, the musically-carrying out activity can not be fruitful. An important role in carrying out 